\title{
PENGARUH PENGAWASAN PIMPINAN TERHADAP DISIPLIN KERJA PEGAWAI KANTOR DESA CARAWALI KECAMATAN WATANG PULU KABUPATEN SIDENRENG RAPPANG
}

\author{
Muhammad Yusuf ${ }^{1}$, Sahar ${ }^{2}$ \\ Fakultas ilmu sosial dan ilmu poltik Universitas Muhammadiyah Sidenreng Rappang \\ Sahar.umsrappang@gmail.com
}

\begin{abstract}
Abstrak
Tujuan dari penelitian ini adalah untuk mengetahui pengaruh pengawasan kepemimpinan terhadap disiplin kerja karyawan di kantor Desa Carawali, Kecamatan Watang Pulu, Kabupaten Sidenreng Rappang dan faktor-faktor yang memengaruhi pengawasan pengawasan disiplin kerja karyawan di kantor Desa Carawali kecamatan watang Pulu, Kabupaten Sidenreng Rappang. Populasi dalam penelitian ini adalah 54 orang. Perhitungan sampel menggunakan sampling jenuh, yaitu, mengambil semua populasi sebagai sampel adalah sebanyak 54 orang. Jenis penelitian ini adalah deskriptif kuantitatif. Hasil dari penelitian ini adalah pengawasan pimpinan terhadap disiplin kerja karyawan di kantor Desa Carawali kecamatan watang pulu Kabupaten Sidenreng Rappang tidak memiliki pengaruh signifikan terhadap melihat data yang diproses dalam tabel ANOVA, ternyata nilai $t$ adalah $\leq t$ tabel atau $1,11 \leq 2,00$ dan taraf signifikansi $0,27(F>0,05)$ maka Ho diterima dan $\mathrm{Ha}$ ditolak, artinya pengawasan kepemimpinan $(X)$ tidak memiliki pengaruh yang signifikan terhadap disiplin kerja karyawan (Y). Faktor-faktor yang mempengaruhi pengawasan dilihat dari faktor pertama yang memiliki pengaruh 22,5\%. Faktor kedua memiliki pengaruh 15,4\%. Faktor ketiga memiliki pengaruh 38,2\% dan faktor keempat memiliki pengaruh 20,3\%.
\end{abstract}

Kata kunci : Pengawasan dan Disiplin

\begin{abstract}
The purpose of this study was to determine the effect of leadership oversight on employee work discipline in the office of Carawali Village, Watang Pulu Subdistrict, Sidenreng Rappang Regency and the factors that influenced the supervisory supervision of employee work discipline at the Carawali Village office in Watang Pulu District, Sidenreng Rappang District. The population in this study were 54 people. Calculation of samples using saturated sampling, that is, taking all the population as a sample is as many as 54 people. This type of research is quantitative descriptive. The results of this study are the leadership supervision of employee work discipline in the Carawali Village office in Watang Pulu District, Sidenreng Rappang District, which has no significant effect of seeing the processed data in the ANOVA table, it turns out that the $t$ value is $\leq t$ table or $1.11 \leq$ 2.00 and significance level 0.27 ( $F>0.05)$ then $\mathrm{Ho}$ is accepted and $\mathrm{Ha}$ is rejected, meaning that leadership supervision $(X)$ does not have a significant effect on employee work discipline $(Y)$. The factors that influence supervision are seen from the first factor which has an influence of $22.5 \%$. The second factor has an influence of $15.4 \%$. The third factor has an influence of $38.2 \%$ and the fourth factor has an influence of $20.3 \%$.
\end{abstract}

Keywords:supervision and work discipline 


\section{A. PENDAHULUAN}

Penerapan otonomi daerah menjadikan revitalisasi desentralisasi sangat penting artinya dalam rangka peningkatan kinerja birokrasi pemerintahan, penyediaan dan pelayanan sehingga dapat memacu peningkatan efisiensi serta pemantapan daya saing. Berkaitan dengan hal itu desentralisasi birokrasi pemerintahan, penyediaan dan pelayanan pada masyarakat secara nyata, efisien dan bertanggung jawab perlu lebih dipercepat mengacu kepada arah kebijaksanaan desentralisasi otonomi daerah, hal tersebut diberlakukan Undang-undang Nomor 32 Tahun 2004 tentang Pemerintahan Daerah. Peningkatan kebutuhan Aparatur sipil negara bertujuan mengubah sikap perilaku mereka menjadi perilaku yang dapat melaksanakan segala aktifitas disemua bidang, pada dasarnya perilaku manusia dapat mempengaruhi setiap tindakan dalam mencapai tujuan yang ingin dicapai.

Sumber daya manusia yang berkualitas yaitu masalah sangat penting dalam persaingan saat ini. Pemberdayaan SDM yang maksimal dapat memungkinkan organisasi agar mampu bersaing dan menghasilkan efesiensi serta efektifitas proses produksinya, komponen SDM yang sangat begitu vital suatu organisasi adalah pegawai, karna setiap organisasi pegawai mampu mempunyai peranan yang sangat penting untuk pencapaian tujuan organisasi, sehingga setiap pegawai dituntut untuk bekerja secara maksimal dengan efektif dan efesiensi, yang mana untuk menghasilkan seorang pegawai yang berkualitas di perlukan pemberdayaan.Alternatif untuk meningkatkan pemberdayaan para pegawai tersebut adalah dengan meningkatkan disiplin kerja. Keberadaan disiplin kerja menjadi sangat penting karena dengan dalam suasana kerja yang penuh disiplin suatu kantor dapat melaksanakan program kerja yang telah direncanakan. Tata peraturan menjadi acuan bagi Aparatur untuk dapat menjadi pegangan bersama serta sekaligus dapat menyatukan dan menyelaraskan berbagai tujuan serta tata nilai individual yang dianut oleh para aparatur (Yoesana 2013).

Disiplin kerja sangat menekankan untuk upaya penyadaran serta pembentukan sikap perilaku aparatur agar mematuhi tata peraturan yang telah disusun oleh suatu instansi. Penyadaran serta pembentukan perilaku akan membentuk keselarasan antara tujuan individu masing-masing aparatur dengan tujuan kantor. Kantor harus mampu dapat membuat kebijakan untuk mendorong peningkatan disiplin kerja pegawai. Tahap awal yaitu menata peraturan kerja sebagai kerangka acuan bagi aparatur. Tahap kedua yaitu menerapkan pengawasan agar dapat membentuk karakter disiplin, dan tahap yang ketiga yaitu budayakan disiplin kerja dikalangan para aparatur itu sendiri. Penegakan disiplin kerja tidak bisa diserahkan kepada aparatur semata sehingga suatu instansi mesti mempunyai suatu pembinaan disiplin para aparaturnya.

Pembinaan disiplin dapat diwujudkan dengan berbagai cara mendorong para aparatur untuk patuh dan taat terhadap berbagai peraturan yang ada di instansi tersebut supaya dapat mencegah terjadinya pelanggaran terhadap peraturan yang berlaku sehingga tujuan utama untuk pembinaan disiplin kerja diri diantara para aparatur. Disiplin merupakan suatu tindakan manajemen agar dapat mendorong para organisasi untuk memenuhi tuntutan diberbagai ketentuan tersebut, dengan dengan kata lain kedeisiplinan aparat adalah bentuk pelatihan yang berusaha untuk memperbaiki dan membentuk pengetahuan, sikap perilaku aparatur sehingga para aparat dengan sukarela dapat berusaha secara kerjasama dan para aparat yang lain serta dapat meningkatkan prestasi kinerjanya.

Disiplin merupakan suatu fungsi operasional MSDM yang sangat penting hal demikian dikarenakan semakin baik tingkat disiplin kerja aparatur, maka akan semakin baik kinerja yang akan dicapainya. Tanpa adanya disiplin yang baik, akan sulit bagi organisasi untuk dapat mencapai hasil yang baik serta juga merupakan factor utama yang diperlukan sebagai alat peringatan terhadap aparat yang tidak mau merubah sifat dan perilaku sehingga seorang aparatur dikatakan memiliki disiplin yang baik jika aparat tersebut memiliki rasa tanggung jawab terhadap tugas yang diembangya.

Menurut Hasibuan (2006:444) bahwa, disiplin kerja adalah kesadaran dan kerelaan seseorang dalam menaati semua peraturan perusahaan dan norma-norma sosial yang berlaku. Sesuai dengan hal tersebut maka dapat dikatakan bahwa disiplin 
merupakan sikap, tingkah laku dan perbuatan yang sesuai dengan peraturan perusahaan baik yang tertulis maupun yang tidak tertulis. Peraturan yang dimaksud termasuk absensi, lambat masuk, serta cepat pulang karyawan. Hal ini merupakan suatu sikap indisipliner karyawan yang perlu disikapi dengan baik oleh pihak manajemen. Banyak yang mengartikan disiplin yaitu karyawan selalu datang serta pulang tepat pada waktunya. Pendapat itu hanya salah satu yang dituntut oleh organisasi.

Desa Carawali merupakan Desa di Kecamatan Watang Pulu dan menjadi salah satu Desa percontohan di Kabupaten Sidenreng Rappang, namun berdasarkan pengamatan calon peneliti di lapangan pada saat magang tanggal 2 Februari sampai 2 Maret 2018, khususnya mengenai pegawai di Kantor Desa Carawali belum mengikuti aturan yang ada, dengan tidak datang tepat pada waktunya dan terkadang masih menggunakan pakaian yang tidak sesuai dengan aturan yang telah ditetapkan, kemudian tidak melayani masyarakat yang ingin mengurus berkas secara tepat waktu, sehingga ada keluhan dari masyarakat yang datang ke Kantor Desa Carawali. Maka dapat dikatakan bahwasanya pegawai di Kantor Desa Carawali masih belum disiplin dalam ketepatan waktu, ketaatan terhadap aturan dan tanggung jawab pekerjaannya. Hal tersebut terjadi diasumsikan karena kurangnya pengawasan dari pimpinan.

Menurut Melayu Hasibuan (2005:194) pengawasan dapat merangsang disiplin kerja pegawai, dengan adanya pengawasan pegawai akan merasa mendapat perhatian, bimbingan, petunjuk, arahan dari pimpinan, dan pimpinan secara langsung dapat mengetahui kemampuan dan kedisiplinan setiap individu untuk memberikan penilaian yang objektif, oleh karena itu dalam sebuah organisasi publik maupun organisasi privat mutlak diperlukan sistem pengawasan yang baik agar tercipta pengawasan internal yang dapat mengurangi kesalahan-kesalahan dan mendukung disiplin kerja pegawai, sejalan dengan hal tersebut menurut Kartono (2002:15) Pengawasan adalah kegiatan mengamati, observasi menilai, mengarahkan pekerjaan, wewenang yang diserahkan oleh atasan terhadap bawahannya, sehingga dapat diberikan sanksi terhadap bawahan secara struktural, yang dilakukan secara berkelanjutan dan berkesinambungan, sedangkan indikator pengawasan yang akan dipergunakan dalam pengukuran variabel yaitu menentukan ukuran pelaksanaan, memberikan penilaian, dan mengadakan korektif.

Berdasarkan uraian masalah tersebut maka penulis mengangkat rancangan judul penelitian yaitu " Pengaruh Pengawasan Pimpinan terhadap Disiplin Kerja Pegawai di Kantor Desa Carawali Kecamatan Watang Pulu Kabupaten Sidenreng Rappang" dengan tujuan untuk mengetahui Pengaruh Pengawasan Pimpinan terhadap Disiplin Kerja Pegawai di Kantor Desa Carawali Kecamatan Watang Pulu Kabupaten Sidenreng Rappang dan untuk mengetahui Faktor-faktor yang memengaruhi Pengawasan Pimpinan terhadap Disiplin Kerja Pegawai di Kantor Desa Carawali Kecamatan Watang Pulu Kabupaten Sidenreng Rappang.

\section{Konsep Pengawasan}

Pengawasan merupakan suatu proses pengamatan semua kegiatan yang dilakukan oleh organisasi guna menjamin bahwa pekerjaan yang sedang dilakukan harus sesuai dengan apa yang telah di temtukan sebelumnya, selain itu juga merupakan usaha sadar dan sistematik untuk lebih menjamin bahwa semua tindakan operasional yang diambil dalam organisasi benar-benar sesuai dengan rencana yang telah ditentukan sebelumnya. Pengertian di atas menunjukkan bahwa pengawasan sebagai fungsi dalam manajemen yang harus dilaksanakan. Istilah pengawasan masih dipergunakan dalam bentuk yang berbedabeda antara lain pemeriksaan, pengendalian, pengamatan, pemantauan dan sebagainya, namun pada dasarnya kesemuanya itu dilakukan demi mencapai tujuan organisasi yang telah ditentukan sebelumnya.

Menurut Arifin Abdul Rachman (2001: 23) pengawasan mempunyai tujuan untuk menjamin ketetapan pelaksanaan sesuai dengan rencana kebijakan dan perintah, menertibkan koordinasi kegiatan-kegiatan, mencegah pemborosan dan penyelewengan, menjamin terwujudnya kepuasan masyarakat atas barang atau jasa yang dihasilkan, membina kepercayaan masyarakat terhadap kepemimpinan organisasi, dengan demikian mengenai tujuan pengawasan sangat erat 
kaitannya dengan rencana dari suatu organisasi.

Pengawasan adalah menentukan apa yang telah dicapai, mengevaluasi dan menerapkan tindakan korektif, jika perlu memastikan sesuai dengan rencana (Muchsan dalam Siswanto Sunarno, 2005:97) dan sejalan dengan hal tersebut maka calon peneliti menggunakan teori Kartono, (2002:15) yang mendifinisikan pengawasan adalah kegiatan mengamati, observasi menilai, mengarahkan pekerjaan, wewenang yang diserahkan oleh atasan terhadap bawahannya sehingga dapat diberikan sanksi terhadap bawahan secara struktural, yang dilakukan secara berkelanjutan dan berkesinambungan, sedangkan indikator pengawasan yang akan dipergunakan dalam pengukuran variabel ini adalah sebagai berikut :

a. Menentukan ukuran pelaksanaan (standar)Artinya cara-cara untuk mengukur pelaksanaan yang berkesinambungan atau beberapa syarat minimal melakukan pengawasan dalam suatu waktu seperti satu kali seminggu atau beberapa kali sebulan bahkan mungkin beberapa jam setiap hari.

b. Memberikan penilaian (evaluate)Artinya memberi nilai kesetiap pekerjaan yang diberikan kepada bawahan, apakah pekerjaannya baik atau jelek.

c. Mengadakan korektif (corretive) artinya Tindakan koreksi ini dimaksudkan sebagai koreksi internal yaitu mengevaluasi berbagai metode pengawasan yang ada seperti standar yang terlalu tinggi dari kebijakan yang dibuat, dan koreksi eksternal yaitu memberikan sanksi kepada bawahan.

Proses pengawasan memerlukan laporan yang dapat menyesuaikan bentukbentuk penyimpangan kearah pencapaian tujuan yang telah ditetapkan sebelumnya dan juga dengan adanya laporan tersebut maka dapat menjadi acuan untuk menilai hasil kerja karyawan ataupun melihat pencapaian tujuan dari organisasi.

\section{Konsep Disiplin Kerja}

Disiplin pegawai adalah perilaku seseorang yang sesuai dengan peraturan, prosedur kerja yang ada atau disiplin adalah sikap, tingkah laku dan perbuatan yang sesuai dengan peraturan dari organisasi baik tertulis maupun yang tidak tertulis (Sutrisno, 2009:94). Disiplin kerja adalah suatu alat yang digunakan para manajer untuk berkomunikasi dengan karyawan agar mereka bersedia mengubah suatu perilaku serta sebagai suatu upaya untuk meningkatkan kesadaran dan kesediaan seseorang untuk mentaati semua peraturan perusahaan dan norma-norma sosial yang berlaku (Veithzal, 2006:444).

Menurut Hasibuan (2009:193), "Disiplin merupakan kesadaran serta kesediaan seseorang untuk mentaati peraturan yang ada di dalam organisasi dan norma-norma sosial yang berlaku, berdasarkan pendapat tersebut, dapat disimpulkan bahwa disiplin kerja merupakan kesediaan karyawan untuk menaati aturan serta norma-norma yang berlaku di dalam perusahaan baik itu aturan yang tertulis maupun aturan yang tidak tertulis. Adapun indikator disiplin kerja yang digunakan calon peneliti yakni menurut Alfred R. Lateiner (Reza, 2014: 16) yaitu:

a. Disiplin waktudiartikan sebagai sikap atau tingkah laku yang menunjukkan ketaatan terhadap jam kerja yakni kehadiran dan kepatuhan pegawai pada jam kerja, pegawai melaksanakan tugas dengan tepat waktu dan benar.

b. Disiplin Peraturan dan Berpakaian artinya Peraturan maupun tata tertib yang secara tertulis dan tidak tertulis dibuat supaya tujuan organisasi dapat tercapai dengan baik, dengan demikian dibutuhkan sikap setia dari pegawai terhadap komitmen yang telah ditentukian tersebut.

c. Disiplin Tanggung Jawab Kerja merupakan salah satu wujud dari tanggung jawab aparatur yaitu penggunaan serta pemeliharaan peralatan dengan baik sehingga dapat menunjang segala kegiatan yang ada kantor agar berjalan dengan lancar, serta adanya kesanggupan dalam menghadapi setiap yang menjadi tanggung jawabnya sebagai seorang aparatur.

\section{Faktor-faktor yang Mempengaruhi Pengawasan}

Adanya berbagai faktor yang membuat pengawasan semakin diperlukan oleh setiap organisasi. Menurut Malayu Hasibuan (2013:363) faktor-faktor tersebut adalah: 
a. Lingkungan Organisasi artinya Melalui fungsi pengawasan manajer mendeteksi segala perubahan yang berpengaruh pada barang dan jasa organisasi, sehingga mampu menghadapi atau memanfaatkan kesempatan yang diciptakan perubahanperubahan yang terjadi.

b. Peningkatan Kompleksitas Organisasinya Semakin besar organisasi semakin besar juga memerlukan pengawasan yang lebih formal serta berhati-hati. Berbagai jenis produk mesti harus diawasi agar dapat menjamin bahwa kualitas dan profitabilitas tetap terjaga.

c. Kesalahan artinya Sistem pengawasan memungkinkan manajer mendeteksi kesalahan-kesalahan yang ada sebelum menjadi kritis.

d. Kebutuhan pimpinan untuk mendelegasikan wewenang artinya Bilamana manajer mendelegasikan wewenang kepada bawahannya, tanggung jawab atasan itu sendiri tidak berkurang. Satu-satunya cara manajer dapat menentukan apakah bawahan telah melakukan tugas-tugas yang telah dilimpahkan kepadanya adalah dengan mengimplementasikan sistem pengawasan.

\section{B. METODE PENELITIAN}

Jenis penelitian ini menggunakan tipe penelitian deskriftif kuantitaif dengan dua variabel yakni variabel $X$ dan variabel $Y$. Adapun populasi dalam hal ini yakni, keseluruhan pegawai dan anggota struktural organisasi di Desa Carawali yang berjumlah 54 orang dan menggunakan sampel jenuh yakni mengambil semua populasi sebagai sampel sebanyak 54 orang.Teknik pengumpulan data yang digunakan yakni observasi, wawancara, kuisioner dan studi kepustakaan serta menggunakan tehnik analisis data dengan bantuan program SPSS for windows, hasil analisis berupa statistik deskriptif, uji kualitas data, analisis deskriptif jenis data interval, dan analisis regresi linear sederhana dan uji hipotesis.

\section{HASIL DAN PEMBAHASAN}

\section{Melayu Hasibuan}

(2005:194)

pengawasan dapat merangsang disiplin kerja pegawai, dengan adanya pengawasan pegawai akan merasa mendapat perhatian, bimbingan, petunjuk, arahan dari pimpinan, dan pimpinan secara langsung dapat mengetahui kemampuan dan kedisiplinan setiap individu bawahannya untuk memberikan penilaian yang objektif, oleh karena itu dalam sebuah organisasi publik maupun organisasi privat mutlak diperlukan sistem pengawasan yang baik agar tercipta pengawasan internal yang dapat mengurangi kesalahan-kesalahan dan mendukung disiplin kerja pegawai.

\section{Pengaruh pengawasan terhadap disiplin kerja pegawai}

Hasil dari uji coefficietnsdikemukakan nilai konstanta $(a)=20,999$ dan beta $=0.166$ serta $t_{\text {-hitung }}$ dan tingkat signifikansi $=0.271$, maka model regresi yang digunakan dalam penelitian ini untuk mengukur pengaruh pengawasan pimpinan terhadap disiplin kerja pegawai di kantor Desa Carawali Kecamatan Watang Pulu Kabupaten Sidenreng Rappang, dapat dianalisa berdasarkan koefisisenkoefisiennya sebagai berikut :

$Y=20,999+0.166 X$

Fungsi regresi di atas, maka dapat dijelaskan jika variabel pengawasan pimpinan (X) berubah, maka disiplin kerja pegawai $(Y)$ juga akan berubah. Tanda positif menunjukkan perubahan yang searah. Apabila pengawasan pimpinan meningkat, maka disiplin kerja pegawai juga akan meningkat dengan koefisien regresi sebesar 0,166 dan sebaliknya, jika pengawasan pimpinan menurun, maka Kualitas disiplin kerja pegawai juga akan menurun dengan koefisien sebesar 0,166 . Nilai konstanta sebesar 20.999 menunjukkan bahwa, jika semua variabel konstan maka pengawasan pimpinan masih bersifat positif dan Nilai beta 0,166 diketahui bahwa variabel tidak berpengaruh dominan terhadap disiplin kerja pegawai $(\mathrm{Y})$, berdasarkan nilai beta yang kecil.

Hasil dari uji ANOVApada bagian ini ditampilkan hasil yang diperoleh adalah nilai $\mathrm{F}=1,238$ dengan tingkat probabilitas sig 0.271 , untuk menguji kebenaran hipotesis dalam penelitian ini, dilakukan uji $F$. Untuk mengetahui bahwa ada pengaruh/signifikan dapat diketahui dengan melihat dari level of significant $a=0,05$. Jika nilai signifikansi lebih kecil dari 0,05 maka Ho ditolak dan $\mathrm{Ha}$ diterima, berdasarkan hasil olah data pada tabel ANOVA, maka diketahui $F_{\text {hitung yang }}$ diperoleh sebesar 1,238 dengan tingkat 
signifikansi $0,27(F>0,05)$ yang berarti variabel pengawasan pimpinan $(X)$ tidak mempunyai pengaruh yang signifikan terhadap disiplin kerja pegawai $(\mathrm{Y})$ di kantor Desa Carawali. Uji statistik $t$ untuk menunjukkan seberapa besar pengaruh satu variabel penjelas/independen secara individual menerangkan variasi variabel dependen, berdasarkan tabel coefficients hasil olah data SPSS, maka diketahui bahwa

a. Nilai $t$ hitung variabel pengawasan pimpinan (X) 1,11 dengan tingkat signifikansi 0,27 .

b. Hipotesis berdasarkan uji $t$ dirumuskan secara statistik sebagai berikut:

$\mathrm{Ha}: \mathrm{P}_{\mathrm{yx}} \neq 0$

Ho : : $P_{y x}=0$

Hipotesis bentuk kalimat:

a. HipotesisHa :Pengawasan pimpinanberpengaruhsignifikanterhada

p Disiplin kerja pegawai di kantor Desa Carawali Kecamatan Watang Pulu Kabupaten Sidenreng Rappang.

b. HipotesisHo :Pengawasan pimpinann tidakberpengaruhsignifikanterhadap

Disiplin kerja pegawai di kantor Desa Carawali Kecamatan Watang Pulu Kabupaten Sidenreng Rappang.

Pengambilankeputusan :

a) Jikanilai $t$ hitung $\geq t$ tabelmaka Ho ditolakdan $\mathrm{Ha}$ diterima, artinyaberpengaruhsignifikan .

b) Jikanilai $t$ hitung $\leq t$ tabelmaka Ho diterimadan $\mathrm{Ha}$ ditolak, artinyatidakberpengaruhsignifikan

.TabelCoefficientsdiperolehnilai $\mathrm{t}$ hitung= 1,11prosedurmencari statistic tabeldengankriteria :

1) Tingkat signifikan $(a=0,05)$ untukujiduapihak

2) dfataudk (derajatkebebasan) = jumlah data -2 atau $54-2=52$

3) di dapat $t_{\text {tabel }}=2,00$

keputusan :

Ternyata nilai $\mathrm{t}_{\text {hitung }} \leq \mathrm{t}$ tabelatau $1,11 \leq 2,00$ maka Ho diterimadan $\mathrm{Ha}$ ditolak, artinya Pengawasan pimpinan tidakberpengaruhsignifikanterhadap Disiplin kerja pegawai di kantor Desa Carawali Kecamatan Watang Pulu Kabupaten Sidenreng Rappang.

Hasil dari uji summary yakni

a. $r$ adalah 0,153 b. $r$ Square : $0,023 \times 100 \%=2,3 \%$ ( pengaruh $X$ terhadap $Y$ )

Sisanya $100 \%-2,3=97,7 \%$ (sisanya dipengaruhi oleh faktor yang lain) Koefesien determinasi $\left(r^{2}\right)$ digunakan untuk mengetahui pengaruh $X$ terhadap $Y$ dalam menerangkan variasi variabel dependen. Berdasarkan tabel model summery koefisien determinasi $(r)$ atau $r$ squared $=0,023$ berarti secara bersama-sama $2,3 \%$ perubahan variabel Disiplin Kerja Pegawai (Y) dapat dijelaskan oleh variabel Pengawasan Pimpinan (X), atau dengan kata lain pengaruh variabel bebas terhadap variabel terikat sebesar $2,3 \%$, sedangkan sisanya yaitu $97,7 \%$ dipengaruhi oleh variabel lain yang tidak masuk dalam kerangka konsep penelitian ini.

Berdasarkan hasil yang ada diatas dapat dilihat bahwa pengawasan yang di lakukan oleh pimpinan kepada bawahannya masih tergolong rendah, hal tersebut disebabkan karena pimpinan tidak selalu hadir di kantor, untuk itu disiplin kerja pegawai juga masih tergolong rendah, di samping itu gaji pegawai yang belum dibayarkan atau seringnya mengalami keterlambatan dalam proses pemberian gaji sehingga menyebabkan pegawai tidak disiplin dalam hal aturan jam kantor, sebagaimana yang diatur dalam UU.No 13 Tahun 2003, yaitu yang tertera dalam pasal 77 ayat 1 dijelaskan bahwa jam kerja karyawan yang bekerja 6 hari dalam seminggu dikenakan 7 jam kerja dalam sehari atau 40 jam dalam seminggu, sementara jam kerja karyawan yang bekerja 5 hari dalam seminggu dikenakan 8 jam kerja dalam sehari atau 40 jam dalam seminggu yakni mulai pukul 08:00 sampai pukul 15:00.

Hal tersebut sependapat dengan apa yang telah dikemukakan oleh Maslow yang dikutip oleh Stephen P. Robbins and Timothy A. Judge (2008) salah satu indikator dalam meningkatkan disiplin pegawai yaitu tercapainya kebutuhan keamanan dan rasa aman artinya kebutuhan yang dapat memberikan pengembangan dan gaji kepada pegawai.

\section{Faktor- faktor yang memengaruhi pengawasan}


Faktor kesalahan- kesalahan kerja di kantor Desa Carawali menjadi faktor yang paling berpengaruh sebanyak $38,2 \%$ dari empat faktor yang ada yakni faktor perubahan lingkungan, faktor peningkatan komplesitas, faktor pendelegasian wewenang dan dapat disimpulkan bahwa pegawai harus bekerja dengan baik dan teliti agar tidak terjadi kesalahan-kesalahan dan tidak mendapatkan sanksi dari pimpinan.

\section{KESIMPULAN}

Berdasarkan hasil penelitian yang telah di uraikan, maka dapat disimpulkan bahwa :

1. Pengawasan pimpinan terhadap disiplin kerja pegawai di kantor Desa Carawali Kecamatan Watang Pulu Kabupaten Sidenreng Rappang tidak memiliki pengaruh yang signifikan melihat dari hasil olahan data pada tabel ANOVA, ternyata nilai $\mathrm{t}$ hitung $\leq \mathrm{t}$ tabelatau $1,11 \leq 2,00$ dan tingkat signifikansi 0,27 ( $F>0,05)$ maka $\mathrm{Ho}$ diterimadan $\mathrm{Ha}$ ditolak, artinya Pengawasan pimpinan (X) tidakberpengaruhsignifikanterhadap Disiplin kerja pegawai (Y).

2. Faktor-faktor yang memengaruhi pengawasan dilihat dari faktor yang pertama perubahan lingkungan organisasi memiliki pengaruh sebesar $22,5 \%$. Faktor yang kedua peningkatan kompleksitas organisasi memiliki pengaruh sebesar $15,4 \%$. Faktor yang ketiga kesalahankesalahan memiliki pengaruh sebesar $38,2 \%$ dan faktor yang keempat pendelegasian wewenang memiliki pengaruh sebesar $20,3 \%$.

\section{E. REFERENSI}

\section{A. Buku}

Ahmad, Jamaluddin. 2015. Metode Penelitian Administrasi Publik (Teori dan Aplikasi). Gava Media. Yogyakarta.

Aka Hawari. 2012. Guru Yang Berkarakter Kuat. Laksana. Jogjakarta.

A.F Stoner. 2000. Manajemen jilid 1. Erlangga. Jakarta.
Abdul Rachman, Arifin. 2001. Administrasi Pemerintahan Dalam Pembangunan. CV. Haji Mas Agung. Jakarta.

Arikunto, Suharsimi. 2013. Prosedur Penelitian Suatu Pendekatan Praktik. Rineka Cipta. Jakarta.

Achmad, Sobirin 2007. Budaya Organisasi Pengertian, Makna dan Aplikasinya.

Dalam Kehidupan Organisasi.IBPP STIM YKPN.Yogyakarta.

Bungin, Burhan. 2005.Metode Penelitian Kuantitatif. Prenadamedia. Jakarta.

Hasibuan, Malayu S.P. 2005. Manajemen Sumber Daya Manusia. Edisi Revisi. Bumi Aksara.Jakarta

2006. Manajemen Dasar, Pengertian, dan Masalah. Edisi Revisi. Bumi Aksara. Jakarta.

2009.

ManajemenDasar, Pengertian, Dan Masalah. PT Bumi Aksara. Jakarta.

2013. Manajemen Sumber Daya Manusia. PT Bumi Aksara. Jakarta.

Henry, Simamora. 2004. Manajemen Sumber Daya Manusia Edisi Ketiga. STIE YPKN. Yogyakarta.

Kartono, Kartini. 2002. Pemimpin dan Kepemimpinan .PT. Grafindo Persada. Jakarta.

Laksmi, dkk. 2008. Manajemen Perkantoran Modern. Penaku.Jakarta.

Manullang, $\mathrm{M}$ dan Marihot A.M.H Manullang. 2004. Manajemen Personalia. Gajah Mada University Press.Yogyakarta.

Muchsan, Siswanto Sunarno. 2005. Hukum Pemerintahan Daerah. Sinar Grafika. Jakarta.

Priyatno. 2012. Cara Kilat Belajar Analisis Data dengan SPSS 20. Edisi Kesatu. Andi. Yogyakarta. 
Rivai, Veithzal, dkk.. 2011. Corporate Performance Management dari teori ke Praktek. Ghalia Industri. Bogor.

Robbins, Stephen P. 2003. Perilaku Organisasi. Jilid 2. PT. Indeks Kelompok Gramedia. Jakarta.

Soejono. 2000. Sistem dan Prosedur Kerja, Edisi Kelima. Penerbit Bumi Aksara. Jakarta.

Sujamto. 2001. Kebijakan Kinerja Karyawan; Kiat Membangun Organisasi Kompetitif Menjelang Perdagangan Bebas Dunia. BFFE.Yogyakarta.

Siswanto, Sunarno. 2006. Hukum Pemerintahan Daerah di Indonesia. Sinar Grafika. Jakarta.

Sutrisno, Edi. 2009. Manajemen Sumber Daya Manusia Edisi pertama. Kencana Prenada Media Group.Jakarta.

Sugiyono. 2013. Metodelogi Penelitian Kuantitatif, Kualitatif Dan R\&D. ALFABETA. Bandung.

S.P, Hasibuan, Malayu. 2013. Manajemen Sumber Daya Manusia. PT Bumi Aksara. Jakarta.

Syofian, Siregar. 2015. Metode Penelitian Kuantitatif Dilengkapi Dengan Perbandingan Perhitungan Manual \& SPSS. Kencana. Jakarta.

Tilaar. 2006. Standarisasi Pendidikan Nasional. Rineka Cipta. Jakarta.

Wursanto. 2005. Dasar-Dasar IImu Organisasi. Andi.Yogyakarta.

\section{B. Jurnal Skripsi :}

Ananto, Reza, 2014. Skripsi. Analisis Pengaruh Gaya Kepemimpina, Motivasi Dan Disiplin Kerja Terhadap Kinerja Karyawan (Study Impiris Pada PT DHL Global Forwading Semarang Branch.). Universitas Diponergoro Semarang.
Jumriana. 2018. Skripsi. Pengaruh Pengawasan Melekat terhadap Disiplin Kerja Pegawai di Kantor Kecamatan Baranti kabupaten Sidenreng Rappang. STISIP Muhammadiyah Rappang. Rappang.

Rusni. 2017. Skripsi. Pengaruh Pengawasan terhadap Disiplin Kerja Aparatur pada Kantor Kecamatan Tiroang Kabupaten Pinrang. STISIP Muhammadiyah Rappang. Rappang.

Yoesana, U. 2013. Hubungan Antara Motivasi Kerja Dengan Disiplin Kerja Pegawai.1(1). 13-27.

Zhendy, Citra, Larrynsia, Wijanarko. 2016. Skripsi. Pengaruh Pengawasan Pimpinan terhadap Disiplin Kerja Karyawan pada Pabrik Mesin Industri Kecamatan Geger Kabupaten Madiun. FPIPS IKIP PGRI Madiun. Madiun.

\section{Dokumen :}

Undang-undang No. 32 Tahun 2004 tentang Pemerintahan Daerah

UU No. 13 tahun 2003, yaitu yang tertera dalam Pasal 77 ayat 1

Peraturan menteri dalam negeri nomor 60 tahun 2007

Peraturan pemerintah Republik Indonesia nomor 53 tahun 2010 pasal 1 ayat 1 